\title{
Pathogens co-transported with invasive non-native aquatic species: implications for risk analysis and legislation
}

\author{
Rachel Foster $1,2,3$, Edmund Peeler ${ }^{3}$, Jamie Bojko, ${ }^{4,5}$, Paul F. Clark', \\ David Morritt ${ }^{2}$, Helen E. Roy ${ }^{6}$, Paul Stebbing ${ }^{7}$, Hannah J. Tidbury ${ }^{3}$, \\ Louisa E. Wood ${ }^{3,8}$, David Bass ${ }^{1,3,9}$
}

I Department of Life Sciences, the Natural History Museum, Cromwell Road, London, SW7 5BD, UK 2 School of Life Sciences and the Environment, Royal Holloway University of London, Egham, Surrey, TW20 OEX, UK 3 Centre for Environment, Fisheries and Aquatic Science, Weymouth, Dorset, DT4 8UB, UK 4 School of Health and Life Science, Teesside University, Middlesbrough, TS1 3BA, UK 5 National Horizons Centre, Teesside University, Darlington, DH1 1HG, UK 6 UK Centre for Ecology \& Hydrology, Wallingford, OX10 8BB, UK 7 APEM Ltd, A17 Embankment Business Park, Heaton Mersey, Manchester, SK4 3GN, UK 8 Centre for Blue Governance, University of Portsmouth, Portsmouth, UK 9 Sustainable Aquaculture Futures, Biosciences, University of Exeter, EX4 $4 Q D, U K$

Corresponding author: Rachel Foster (r.foster@nhm.ac.uk)

Academic editor: Anthony Ricciardi | Received 9 July 2021 | Accepted 8 September 2021 | Published 18 October 2021

Citation: Foster R, Peeler E, Bojko J, Clark PF, Morritt D, Roy HE, Stebbing P, Tidbury HJ, Wood LE, Bass D (2021) Pathogens co-transported with invasive non-native aquatic species: implications for risk analysis and legislation. NeoBiota 69: 79-102. https://doi.org/10.3897/neobiota.69.71358

\begin{abstract}
Invasive Non-Native Species (INNS) can co-transport externally and internally other organisms including viruses, bacteria and other eukaryotes (including metazoan parasites), collectively referred to as the symbiome. These symbiotic organisms include pathogens, a small minority of which are subject to surveillance and regulatory control, but most of which are currently unscrutinized and/or unknown. These putatively pathogenetic symbionts can potentially pose diverse risks to other species, with implications for increased epidemiological risk to agriculture and aquaculture, wildlife/ecosystems, and human health (zoonotic diseases). The risks and impacts arising from co-transported known pathogens and other symbionts of unknown pathogenic virulence, remain largely unexplored, unlegislated, and difficult to identify and quantify. Here, we propose a workflow using PubMed and Google Scholar to systematically search existing literature to determine any known and potential pathogens of aquatic INNS. This workflow acts as a prerequisite for assessing the nature and risk posed by co-transported pathogens of INNS; of which a
\end{abstract}

Copyright Rachel Foster et al. This is an open access article distributed under the terms of the Creative Commons Attribution License (CC BY 4.0), which permits unrestricted use, distribution, and reproduction in any medium, provided the original author and source are credited. 
better understanding is necessary to inform policy and INNS risk assessments. Addressing this evidence gap will be instrumental to devise an appropriate set of statutory responsibilities with respect to these symbionts, and to underpin new and more effective legislative processes relating to the disease screening and risk assessment of INNS.

\section{Keywords}

Alien species, invasive pathogen, opportunistic pathogen, parasite, symbiont

\section{Introduction}

Invasive Non-Native Species (INNS) are "species whose introduction by human activity outside their natural past or present distribution threatens biodiversity", as defined by the Convention on Biological Diversity (CBD 2010), and are one of the greatest global threats to biodiversity (IPBES global assessment 2019). New introductions of INNS are increasing every year, with no indication that introduction events are decreasing in frequency (Seebens et al. 2020). It is increasingly recognized that invasions are not the product of single species introduction events but can be considered as holobionts (Skillings 2016): i.e., units of biological organisation including the host and all its symbionts (external and internal), including pathogenic species. Therefore, organisms such as viruses, bacteria, fungi, protists and other (micro-)eukaryotic parasites and pathogens may be introduced to new regions along with their invasive non-native host and can be important factors in the invasion process (Peeler et al. 2011; Roy et al. 2017). A broad basis for referring to these organisms as 'pathogens' is required: they may not be recognized as pathogens, or cause disease in the INNS host transporting them, but may impact on other related (or unrelated) hosts in their new range. Further, pathogenesis can be very context dependent, as described by the symbiotic continuum concept (Bass and del Campo 2020). Therefore, a biologically informed approach to horizon scanning for such 'pathogens' is necessary, to enable effective identification of potentially new and emerging diseases. For the purposes of this paper, to avoid repetition of "parasites/pathogens" to refer to symbionts that take nutritional advantage of their hosts potentially causing disease, we henceforth use "pathogen" as a catch-all term.

In the field of invasion biology, the translocation of non-native pathogens (emerging infectious diseases in public and wildlife health) are increasingly being researched as important environmental driving factors (Ogden et al. 2019; Thakur et al. 2019); however, this is not currently reflected in national and international policy and legislation. For example, co-introduced pathogens are explicitly excluded from the EU Invasive Alien Species Regulation 1143/2014. Instead, potentially invasive co-introduced pathogens are considered as potential impacts of INNS establishment. Although pathogens are currently excluded from much of the legislation surrounding invasive species, there are a few examples where they are included, for example the Ballast Water Management Convention (Hess-Erga et al. 2019). 
Understanding and predicting the impacts of INNS is essential to inform risk analysis, for example, via horizon scanning, risk assessments and impact assessments, which underpin many components of INNS policy and management. However, pathogens associated with most (potential) INNS are very poorly known (Roy et al. 2017; Pagenkopp Lohan et al. 2020), except in the few cases where they are recognized under animal disease or human health legislation and are monitored and reported accordingly. In general, INNS risk analyses focus on the environmental and/or cumulative impacts of INNS, without (specific) reference to co-transported pathogens (e.g., Dick et al. 2017).

Knowledge and policy gaps can result in inadequate scrutiny and assessment of the risks associated with the movement of pathogens into new regions and countries (Hulme 2014; Dunn and Hatcher 2015). This has been recognized with a call for the prioritization of empirical research required to cover knowledge gaps about transmitted pathogens (Chinchio et al. 2020). Therefore, a framework for quantifying and documenting our existing knowledge of INNS and associated pathogens which may also become introduced with host movements is vital. This involves conducting literaturebased and pathogen screening to fill knowledge gaps where such information is lacking. These data will then lead to the development of invader pathogen profiles, outlining what is known about the invader's pathogens and those of related taxa. A complexity in this process is the diversity within the pathogen profile of a given species across its invasive range (e.g., Bojko et al. 2018), where any single INNS may have multiple different disease profiles across its native and invasive range, which will also change over time. This potential spatial and temporal variation in the pathogen profile of a given species could potentially drive the need for more specific risk assessments in relation to invasion risks (i.e., not only a particular species, but also from a particular population).

In this paper we present a workflow to meet these imperatives. This can be applied to INNS already present in a region, those with the potential to arrive, and those already present but yet to establish. For the purposes of this paper, we focus on (potentially) pathogenic symbionts of aquatic INNS of concern to the UK, which may be permanently or transiently associated with one or multiple water bodies. We include all pathogenic symbiont types: viral, microscopic, and macroscopic parasites (including metazoans). The underlying premise can be applied across all habitat types, and all symbionts including pathogens that manipulate behaviors of one or more of their hosts, and symbionts that have no discernible effect on their hosts.

\section{Biology and ecology of pathogens co-transported with INNS}

The movement of INNS beyond their native range can result in changes to established host-pathogen relationships, including INNS losing or gaining parasites (Peeler et al. 2011; Dunn and Hatcher 2015; Vilcinskas 2015). The multitude of potential outcomes resulting from relationship changes are summarized in the schematic shown in Figure 1. The enemy release hypothesis (see glossary) states that INNS can lose their pathogens as they move into a new range, which may be due to ecological factors, or 

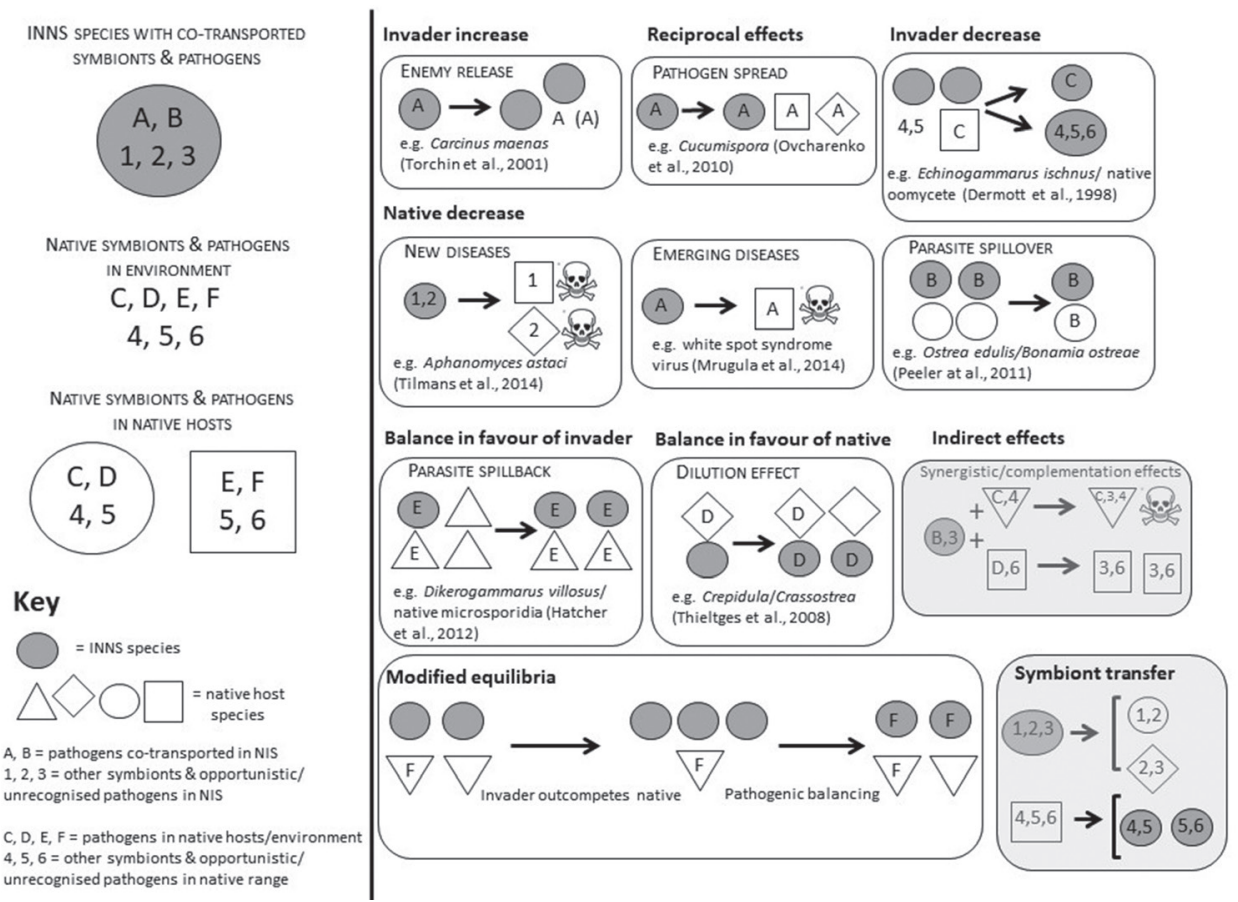

Figure I. Potential fates of symbionts (including pathogens) co-transported with INN host species. The left-hand panel represents a hypothetical INNS with a symbiome comprising pathogens A, B and uncharacterized symbionts 1-3. Potential symbionts already in the native system are pathogens $\mathbf{C}-\mathbf{F}$ and uncharacterized symbionts 4-6. Symbionts can be gained and/or lost by INNS hosts. The main panel on the right presents, with examples, scenarios of gains, losses, and transfers between non-native and native hosts of different species, and outcomes associated with such interactions. Skull and crossbones indicates death/negative effects to native host population. Boxes with gray fill indicate theoretical outcomes for which no empirical evidence was found.

for heteroecious parasites, the absence of a secondary host (Colautti et al. 2004). Cointroduced pathogens can potentially infect native species (Keane and Crawley 2002). In some cases, pathogen loss can also increase invasion success by reducing pathogen burden and associated health costs as well as reducing/eliminating competing susceptible native species (Prenter et al. 2014). Furthermore, lack of co-evolution potentially results in the increased susceptibility of native hosts to the invading pathogen (Taraschewski 2006). For example, a study comparing invasive pathogenicity in cointroduced and native hosts suggests that in $85 \%$ of cases it is higher in native hosts compared to non-native hosts (Lymbery et al. 2014).

Co-introduced pathogens can have significant effects on both native and invasive host evolution, and also different populations of the same host species (Blakeslee et al. 2019a). For example, Rhithropanopeus harrisii has adapted to parasitism by an in- 
troduced castrating rhizocephalan parasite, Loxothylacus panopaei, resulting in much higher pathogen prevalence in its introduced range where the host is naive. This demonstrates the potential consequences of parasite introduction and transmission host populations where they lack an evolutionary relationship (Tepolt et al. 2019). Cointroduced pathogens can also suffer genetic founder effects themselves; this is particularly exhibited in obligate parasitic organisms with complex life cycles. Trematodes infecting the invasive eastern mudsnail (Tritia obsoleta) have been shown to have significantly lower genetic diversity in their introduced range compared to their native range (Blakeslee et al. 2019b).

INNS can also affect native host-pathogen relationships, altering population dynamics and disease transmission. Thieltges et al. (2008) demonstrated that the presence of invasive Crepidula fornicata and Crassostrea gigas significantly reduced the trematode parasite burden of native Mytilis edulis, by interfering with the transmission of freeliving infective trematode larval stages and therefore reducing infection of M. edulis. Host-pathogen ecosystem interactions prove complex, creating challenges for the prediction of invasion success at different locations. The invasive amphipod Echinogammarus ischnus has outcompeted the native Gammarus fasciatus at many locations in the Great Lakes and St. Lawrence River in North America through predation and competition (Dermott et al. 1998). However, a native oomycete infects the invasive E. ischnus and causes greater mortality to the invasive host than to the native $G$. fasciatus, which facilitates the coexistence of the two species in areas of disease prevalence (Kestrup et al. 2011). This relationship is further nuanced in that E. ishnus can also act as a reservoir of the oomycete and facilitate parasite spillback to native amphipods.

Many diseases initially thought to be caused by one primary agent are now known to be the result of interactions between multiple symbionts, the host, and their environment; resulting in the pathobiome concept (Bass et al. 2019). Each INNS individually co-transports its own symbiome, making it difficult to predict its effect on the invaded ecosystem. A survey of symbionts of the invasive green crab Carcinus maenas in its native and invaded range showed many co-transported parasites persisted within the host at its invasion territory (Bojko et al. 2018). The latest approximation suggests this species is associated with -82 known symbionts, many of which are pathogenic and pose risks to native ecosystems and the bioeconomy (Bojko et al. 2020).

The combination of hosts and their symbionts is of more immediate concern than considering the simple transposition of a pathogenic agent, such as a single virus or bacterium. Co-introduction of symbionts with an INNS is more likely to result in pathogen establishment because the co-evolved biological system is already in place to facilitate transmission (Peeler et al. 2011). Generalist pathogens are the main cause for concern since they can utilize native hosts more readily (Peeler et al. 2011). Symbiotic co-invaders may also present parasitic traits in new locations. For example, Aphanomyces astaci, the oomycete agent of crayfish plague, is a non-pathogenic symbiont of many invasive North American crayfish species (Tilmans et al. 2014); however, the introduction of $A$. astaci into Europe has resulted in large-scale mortalities in native crayfish populations, including: Austropotamobius pallipes, Astacus astacus and Astacus leptodactylus. In some cases, their local extinction is possible and has been noted in 


\section{Box I.}

\section{1) Co-transportation of pathogens}

The invasive Asian eel (Anguilla japonica) brought with it the parasitic swim-bladder nematode Anguillicoloides crassus, which has caused high mortalities in native European eels (Anguilla anguilla) and significantly affected the sustainability of future European populations (Peeler et al. 2011). The OIE (World Organisation for Animal Health) - listed pathogen, Bonamia ostreae has caused decimation of native oysters (Ostrea edulis) in Europe, when it arrived with cultivated American populations of O. edulis for aquaculture in the late 1970s (Peeler et al. 2011).

The ornamental trade has been implicated in the introduction of the chytrid Batrachochytrium dendrobatidis; a pathogenic agent partly responsible for the global decline of amphibians and species extinctions (Fisher and Garner 2007). The trade of freshwater molluscs has long caused concern about the potential for snail-mediated zoonotic diseases as they can act as intermediate hosts for parasites of significance to humans and livestock ( $\mathrm{Ng}$ et al. 2016), e.g., angiostrongyliasis in humans caused by the parasitic nematode Angiostrongyliasis cantonensis co-introduced with the invasive snails Pomacea canaliculata and Pomacea maculata.

Symbionts co-transported with INNS may be known pathogens which impact on wildlife in an expanded range (e.g., white spot syndrome virus; Mrugała et al. 2015), or their pathogenic potential may only be revealed when presented with new and susceptible hosts (e.g., the impact of Aphanomyces astaci on native white-clawed crayfish in Europe; Tilmans et al. 2014).

\section{2) Co-transportation of commensal organisms}

The killer shrimp, Dikerogammarus villosus, invaded the UK in 2010, carrying the gregarine protists Uradiophora longissima and Cephaloidophora mucronata characterised from Polish freshwaters (Ovcharenko et al. 2009; Bojko et al. 2013). Gregarines are common commensal organisms of invertebrates that cover a wide symbiotic to parasitic spectrum (Rueckert et al. 2019) and undergo sexual reproduction in the animal gut, releasing spores into the environment that are consumed by other organisms. Uradiophora longissima and C. mucronata appear to be commensal organisms that have co-invaded with their host and do not exhibit any controlling effect upon the killer shrimp population (Bojko et al. 2013). Further molecular and histological studies will better identify commensal species by screening native and invasive populations of high-risk groups, such as the Amphipoda.

\section{3) Invading symbiomes}

Assessing the symbiome of an organism requires the use of multiple tools, including both visualisation (microscopy) and diagnostic (molecular detection) techniques. By understanding the symbiome, we can explore co-infection and approach the invasion from a pathobiome perspective (Bass et al. 2019). The symbiome of the demon shrimp Dikerogammarus haemobaphes, a European invader originating from the Ponto Caspian region, has been shown to include viruses, bacteria, protists (including microsporidia) and metazoans (Bojko et al. 2019; Bojko and Ovcharenko 2019), identifying risks coupled with the invasion process (Bojko et al. 2015; Allain et al. 2020; Subramaniam et al. 2020). For example, the microsporidian parasite, Cucumispora ornata, has been shown to reduce the activity of $D$. haemobaphes and increase its rate of mortality, initiating population control at invasion sites and lowering he direct impact of the host on local biodiversity and the environment. In tandem, this parasite is also capable of infecting native Gammarus pulex, constituting a wildlife risk (Bojko et al. 2019).

Metabarcoding and metagenomic techniques provide us with a capacity to easily pre-screen native species before they may become translocated. Metabarcoding of the UK invasive Homarus americanus cuticle revealed 170 associated bacterial taxa, suggesting that these microbial symbionts may have the capacity to invade with their host (Meres et al. 2012). Without technologies like these being used to advance invasion science, we remain in the dark about the complete symbiome and its associated risks.

many regions (Mrugula et al. 2014). Box 1 details examples of known co-transported pathogens and their effects, co-transported symbionts and how symbiome research can help to assess invasion risks.

\section{INNS in aquatic systems}

Aquatic ecosystems are considered more vulnerable to the effects of INNS introduction and spread than terrestrial ecosystems (Thomaz et al. 2015). Aquatic ecosystems are highly connected, and freshwater catchments link terrestrial, estuarine, and marine 
habitats longitudinally as water moves downstream, providing corridors along which organisms can move easily (Ormerod et al. 2011). Sites at high-risk of INNS introduction occur where vector activity associated with key introduction pathways is high, such as ports, marinas, and aquaculture sites (Keller et al. 2011; Tidbury et al. 2016). Many aquatic organisms have larval stages, which facilitate their dispersal across large distances (Wood et al. 2005). Detection of aquatic INNS often occurs after populations have already established, due to their patchy distribution and low abundance in the early stages of invasion, and difficulty in detecting and identifying early life stages using standard morphological techniques (Ponchon et al. 2013). However, new technologies, such as environmental DNA (eDNA) monitoring, offer increased opportunity for early detection and monitoring for both the host INNS and the associated pathogens (Robinson et al. 2018).

\section{Routes of introduction of aquatic INNS}

The CBD categorizes the pathways of introduction of an invasive species into three main categories; movement of commodities (releases, escapes, contaminants), via transport (stowaway), or by dispersal (corridor, unaided) (Hulme et al. 2008; Pergl et al. 2020). The human-mediated spread of INNS in marine systems is predominantly through global shipping networks via transfer in ballast water or hull fouling on vessels (Tidbury et al. 2016; Bailey et al. 2020). A review of BioInvasions Records showed that in the last 8 years the most common pathway of introduction has been via transport (stowaway), and the most important $\mathrm{CBD}$ pathway category was "ship/boat ballast water" (Stranga and Katsanevakis 2021).

Releases and escapes via the ornamental trade and aquaculture are the most important pathway for freshwater species (Nunes et al. 2015; Stranga and Katsanevakis 2021). The aquatic ornamental animal trade is worth $\$ 25$ billion per annum worldwide and represents a significant invasion pathway (Padilla and Williams 2004). INNS are also introduced through the illegal trade of ornamental aquatic animals. Laws regulating the aquatic pet trade are often poorly communicated and enforced, and in some cases can increase unwanted introductions of banned species (Patoka et al. 2018).

Aquaculture production has expanded rapidly in recent years and global demands are expected to increase to meet the needs of the growing human population (Stentiford et al. 2017). The movement of non-native animals between countries for aquaculture can spread INNS, and the open nature of many aquaculture sites to their surrounding environment can mean that INNS and their symbionts can be released into those environments (Atalah and Sanchez-Jerez 2020). The biggest risk to aquaculture production and growth has been identified as disease (Jennings et al. 2016), which highlights the importance of potential invasive aquatic pathogens and the need to control emerging disease threats. The increasing pressures on aquaculture to support global food security makes minimizing pathogen spill-over to the environment and wildlife, and vice versa, a critical priority to improve both the efficiency of production and ensure environmental sustainability (Stentiford et al. 2020). 
Bait used in recreational fishing is a potential pathway for pathogen introduction and dispersal if anglers dispose of bait or storage water/sediment into aquatic systems (Mahon et al. 2018). Discharge of effluent water from aquaria has also been identified as a high risk for incidental INNS release (Duggan 2010). Transport of live aquatic animals also means that the water in which they are transported becomes a potential source of non-native microbes (Amaral-Zettler et al. 2018). Furthermore, the transit of live animals can produce stressful conditions that can change the microbial communities that they harbour, often leading to disease (Smith et al. 2012). Analysis of imported fish and their carriage water through the supply chain showed increased levels of opportunistic pathogens such as Vibrio spp. (Amaral-Zettler et al. 2018).

Climate change can also facilitate natural range expansion of holobionts (CottierCook et al. 2017). Increased water temperatures, altered hydrodynamics and more frequent extreme weather events are all predicted to increase the rate of aquatic species invasions (Rahel and Olden 2008). Rising water temperatures may mean that more ornamental species, and their symbionts are able to survive and establish. Warmer temperatures also allow pathogenic microbes to complete their life cycle more rapidly and attain higher population densities, increasing their virulence (Dutta and Dutta 2016).

In order to address the knowledge gap between INNS and their symbionts, we propose a literature-based workflow for compiling existing knowledge on a host's symbiome, members of which could be co-transported with INNS. This information is essential for assessing the consequences posed by co-transportation, or any INNS introduction to a new area. Such risks fall into three main categories: 1) pathogenic threats to native hosts or to species cultured or harvested for consumption or trade, 2) trade and legislative implications; for example, listed pathogens being introduced to regions previously considered free of them, and 3) effects of, or changes, to the invading species' symbiome in a new range, conferring novel ecological/behavioural characteristics on the invader.

\section{Material and methods: Literature search methodology}

A list of incoming aquatic INNS of concern to the UK was compiled from the lists of Roy et al. (2014) and a GBNNSS horizon scanning exercise (GBNNSS 2019). Seventy-seven aquatic INNS were identified from these lists (see Table 1). The literature searches were completed between August-October 2020.

To perform the literature search, both PubMed and Google Scholar were used to develop the best methodology (Figure 2). Figure 2 illustrates the workflow options and key considerations for choosing which database to search. Each has different characteristics that may preferentially suit different investigations. Both are subscription-free. The search terms used in this paper are given below; these can be adapted as required. This process can be used/adapted for non-aquatic species and with respect to any geographic region. 


\section{PubMed}

(Species or genus name ${ }^{\#}$ [All Fields]) AND (microbiome[Title/Abstract] OR symbio*[Title/Abstract] OR pathogen*[Title/Abstract] OR parasit*[Title/Abstract] OR protist[Title/Abstract] OR protozoa[Title/Abstract] OR bacteria*[Title/Abstract] OR virus[Title/Abstract] OR host[Title/Abstract] OR reservoir[Title/Abstract] OR vector[Title/Abstract] OR infection [Title/Abstract])

\section{Google Scholar}

"Species name" AND pathogen OR parasite OR commensal OR symbiont OR protist OR bacteria OR virus

"In cases where INNS taxa have recently been subject to taxonomic changes or are taxonomically ambiguous, multiple searches using alternative but equivalent names may be required.

Table I. Non-native species at risk of arriving in the UK, as defined by Roy et al. (2014) and GB-NNSS (2019), and the results of literature searches as described in the main text. [x] is the number of publications informative about co-transported pathogens/symbionts, from which information was extracted and the publication cited in Suppl. material 1. When $\mathrm{x}<4$ in PubMed searches; informative publications were also searched for at INNS genus level (filtering to this degree was not possible or practical with Google Scholar). References for all of the informative publications selected are in Suppl. material 1 and Suppl. material 3. Taxonomic abbreviations: $\mathrm{AL}=$ Algae; $\mathrm{AN}=$ Annelida; $\mathrm{ANG}=$ Angiosperms; $\mathrm{BR}=$ Bryozoa; $\mathrm{CH}=$ Chordata $(\mathrm{CH}-\mathrm{U}=$ Urochordata, $\mathrm{CH}-\mathrm{P}=$ Pisces, $\mathrm{CH}-\mathrm{A}=$ Amphibia, $\mathrm{CH}-\mathrm{R}=$ Reptilia, $\mathrm{CH}-\mathrm{A}=$ Aves, $\mathrm{CH}-\mathrm{M}=$ Mammalia); $\mathrm{CR}=$ Crustacea; $\mathrm{CT}=$ Ctenophora; $\mathrm{EC}=$ Echinodermata; $\mathrm{MO}=$ Mollusca; NE = Nemertea; PL = Platyhelminthes; PO = Porifera .

\begin{tabular}{|c|c|c|c|c|c|}
\hline Species name & Common name & Taxon & $\begin{array}{c}\text { PubMed Genus } \\
\text { search }[\mathrm{X}]\end{array}$ & $\begin{array}{c}\text { PubMed } \\
\text { Species } \\
\text { search }[\mathrm{X}]\end{array}$ & $\begin{array}{c}\text { Google Scholar } \\
\text { Species search } \\
{[\mathrm{X}]}\end{array}$ \\
\hline Aglaothamnion halliae & Brazilian red alga & AL & $1[1]$ & 0 & $34[0]$ \\
\hline Antithamnion pectinatum & Australasian red alga & AL & $2[0]$ & 0 & $40[0]$ \\
\hline Caulerpa taxifolia & killer alga & AL & 43 & $43[8]$ & $2660[4]$ \\
\hline Gracilaria vermiculophylla & rough gar weed & $\mathbf{A L}$ & 90 & $6[4]$ & $1140[4]$ \\
\hline Rugulopteryx okamurae & Asian fan weed & AL & 0 & 0 & $12[\mathbf{0}]$ \\
\hline Eudistylia polymorphal Bispira polyomma & giant feather duster worm & AN & $1[1]$ & 0 & $6[0]$ \\
\hline Marenzelleria wireni & red gilled worm & AN & $1[1]$ & 0 & $17[\mathbf{0}]$ \\
\hline Limnobium spongia & American frog's-bit & ANG & 68 & 0 & $128[\mathbf{1}]$ \\
\hline Saururus cernuus & swamp lily & ANG & $58[0]$ & $2[0]$ & $474[0]$ \\
\hline Trapa natans & water chestnut & ANG & $17[\mathbf{1}]$ & $7[1]$ & $1820[\mathbf{0}]$ \\
\hline Zostera japonica & Japanese seagrass & ANG & $98[71]$ & $1[1]$ & $563[4]$ \\
\hline Schizoporella errata & branching bryozoan & BR & 0 & 0 & $209[\mathbf{0}]$ \\
\hline Ommatotriton ophryticus & northern banded newt & CH-A & 0 & 0 & $21[\mathbf{0}]$ \\
\hline Tadorna ferruginea & ruddy shelduck & CH-A & 21 & $10[\mathbf{1 0}]$ & $562[15]$ \\
\hline Threskiornis aethiopicus & African sacred ibis & CH-A & $7[5]$ & $4[2]$ & $435[2]$ \\
\hline Aonyx cinerea & short clawed otter & CH-M & 232 & $2[2]$ & $166[5]$ \\
\hline Castor canadensis & American beaver & CH-M & 486 & $27[25]$ & $3580[12]$ \\
\hline Myocaster coypus & coypu & CH-M & 52 & $51[43]$ & $2270[27]$ \\
\hline Ondatra zibethicus & muskrat & CH-M & 58 & $42[42]$ & $2650[27]$ \\
\hline Babka gymnotrachelus & racer goby & CH-P & $2[2]$ & $2[2]$ & $80[8]$ \\
\hline Carassius gibelio & Prussian carp & CH-P & 516 & $30[20]$ & $1670[30]$ \\
\hline
\end{tabular}




\begin{tabular}{|c|c|c|c|c|c|}
\hline Species name & Common name & Taxon & $\begin{array}{c}\text { PubMed Genus } \\
\text { search }[\mathrm{X}]\end{array}$ & $\begin{array}{c}\text { PubMed } \\
\text { Species } \\
\text { search }[\mathrm{X}]\end{array}$ & $\begin{array}{c}\text { Google Scholar } \\
\text { Species search } \\
{[\mathrm{X}]}\end{array}$ \\
\hline Gambusia holbrooki & eastern mosquito fish & CH-P & 445 & $15[5]$ & $2660[7]$ \\
\hline Micropterus salmoides & largemouth bass & CH-P & 1,939 & $131[74]$ & $9200[39]$ \\
\hline Neogobius fluviatilis & monkey goby & CH-P & 44 & $6[6]$ & $400[15]$ \\
\hline Neogobius melanostomus & round goby & CH-P & 44 & $35[27]$ & $2050[33]$ \\
\hline Oncorhynchus gorbuscha & pink salmon & CH-P & 1,776 & $30[25]$ & $3560[32]$ \\
\hline Proterorhinus marmoratus & Black Sea tubenose goby & CH-P & $9[6]$ & $2[2]$ & $383[12]$ \\
\hline Proterorhinus semilunaris & western tubenose goby & CH-P & 9 & 7 [4] & $209[\mathbf{1 1}]$ \\
\hline Pterois volitans & red lionfish & CH-P & $13[6]$ & $8[3]$ & $1140[\mathbf{1 2}]$ \\
\hline Umbra pygmaea & eastern mud minnow & CH-P & $5[4]$ & 0 & $215[\mathbf{1}]$ \\
\hline Chelydra serpentina & snapping turtle & CH-R & 22 & $21[\mathbf{1 1}]$ & $2180[\mathbf{1 4}]$ \\
\hline Chrysemys picta & painted turtle & CH-R & 21 & $20[12]$ & $2860[14]$ \\
\hline Ciona savignyi & sea squirt & $\mathrm{CH}-\mathrm{U}$ & 123 & $123[\mathbf{1 2}]$ & $1120[4]$ \\
\hline Styela plicata & pleated tunicate & $\mathrm{CH}-\mathrm{U}$ & $35[6]$ & $15[2]$ & $1350[7]$ \\
\hline Cercopagis pengoi & fishhook water flea & CR & $1[0]$ & $1[0]$ & $624[0]$ \\
\hline Chelicorophium robustum & A Ponto-Caspian amphipod & CR & 0 & 0 & $24[0]$ \\
\hline Chelicorophium sowinskyi & A Ponto-Caspian amphipod & CR & 0 & 0 & $13[0]$ \\
\hline Cherax destructor & common yabby & CR & 81 & $10[6]$ & 1420 [7] \\
\hline Dikerogammarus bispinosus & A Ponto-Caspian amphipod & CR & $22[5]$ & 0 & $27[\mathbf{0}]$ \\
\hline Dyspanopeus sayi & Say's mud crab & CR & $2[1]$ & $2[1]$ & $172[0]$ \\
\hline Echinogammarus ischnus & bald urchin shrimp & CR & $29[21]$ & 0 & $322[2]$ \\
\hline Echinogammarus trichiatus & curly haired urchin shrimp & CR & $29[21]$ & $3[3]$ & $59[3]$ \\
\hline Echinogammarus warpachowskyi & A Ponto-Caspian amphipod & CR & $29[21]$ & 0 & $16[0]$ \\
\hline Hemigrapsus sanguineus & Asian shore crab & CR & 24 & $6[5]$ & $251[4]$ \\
\hline Hemigrapsus takanoi & brush-clawed shore crab & CR & 24 & 0 & $138[3]$ \\
\hline Homarus americanus & American lobster & CR & 119 & $63[38]$ & $8230[42]$ \\
\hline Jaera istri & A Ponto-Caspian isopod & CR & $3[2]$ & $1[1]$ & $72[1]$ \\
\hline Limnomysis benedeni & A Ponto-Caspian mysid & CR & $1[0]$ & $1[0]$ & $169[0]$ \\
\hline Marsupenaeus japonicus & kuruma prawn & CR & 2,088 & $173[65]$ & $4930[28]$ \\
\hline Megabalanus coccopoma & titan acorn barnacle & CR & $4[0]$ & 0 & $108[\mathbf{0}]$ \\
\hline Megabalanus tintinnabulum & sea tulip & CR & $4[0]$ & 0 & $130[1]$ \\
\hline Mytilicola orientalis & red oyster worm & CR & $15[0]$ & $4[0]$ & $349[0]$ \\
\hline $\begin{array}{l}\text { Neocaridina davidi/ Neocaridina } \\
\text { beteropoda }\end{array}$ & cherry shrimp & CR & 8 [4] & $1[0]$ & $93[1]$ \\
\hline Obesogammarus crassus & A Ponto-Caspian amphipod & CR & 0 & 0 & $78[2]$ \\
\hline Obesogammarus obesus & A Ponto-Caspian amphipod & CR & 0 & 0 & $45[1]$ \\
\hline Orconectes rusticus & rusty crayfish & CR & $21[15]$ & $3[2]$ & $1280[5]$ \\
\hline Paramysis lacustris & A Ponto-Caspian mysid & CR & 0 & 0 & $88[0]$ \\
\hline Pontogammarus robustoides & A Ponto-Caspian amphipod & CR & 2 & $1[1]$ & $250[3]$ \\
\hline Procambarus fallax & marbled crayfish & CR & 484 & $1[1]$ & $323[8]$ \\
\hline Rhithropanopeus harrisii & Harris' mud crab & CR & $2[1]$ & $1[1]$ & $1220[\mathbf{1 1}]$ \\
\hline Mnemiopsis leidyi & American comb jelly sea walnut? & CT & 36 & $12[6]$ & $2860[15]$ \\
\hline Asterias amurensis & Northern Pacific seastar & EC & 38 & $8[4]$ & $1890[6]$ \\
\hline Bellamya chinensis & Chinese mystery snail & MO & $27[17]$ & $1[0]$ & $90[3]$ \\
\hline Corbicula fluminalis & Asian clam & MO & $37[18]$ & 0 & $222[0]$ \\
\hline Dreissena rostriformis bugensis & quagga mussel & MO & 79 & $10[2]$ & $683[2]$ \\
\hline Geukensia demissa & Atlantic ribbed mussel & MO & 10 & $9[4]$ & $1750[4]$ \\
\hline Lithoglyphus naticoides & gravel snail & MO & $4[4]$ & $3[3]$ & $373[4]$ \\
\hline Mulinia lateralis & dwarf surf clam & MO & $4[3]$ & $3[2]$ & $906[2]$ \\
\hline Ocinebrellus inornatus & Japanese sting winkle & MO & 0 & 0 & $146[0]$ \\
\hline Potamocorbula amurensis & Amur river clam & MO & 0 & 0 & $887[0]$ \\
\hline Rapana venosa & veined rapa whelk & MO & 12 & $7[3]$ & 965 [4] \\
\hline Sinanodonta woodiana & Chinese giant mussel & MO & 56 & $16[3]$ & $671[4]$ \\
\hline Theora lubrica & Asian semele & MO & 0 & 0 & $162[0]$ \\
\hline Xenostrobus securis & pygmy mussel & MO & $1[0]$ & $1[0]$ & $177[2]$ \\
\hline Cephalothrix simula & $\begin{array}{c}\text { A NW Pacific Ocean nemertean } \\
\text { worm }\end{array}$ & $\mathrm{NE}$ & $2[2]$ & $2[2]$ & $89[7]$ \\
\hline Gyrodactylus salaris & salmon fluke & PL & 422 & $104[0]$ & $2710[\mathbf{0}]$ \\
\hline Celtodoryx ciocalyptoides & cauliflower sponge & PO & $1[0]$ & 0 & $21[0]$ \\
\hline
\end{tabular}




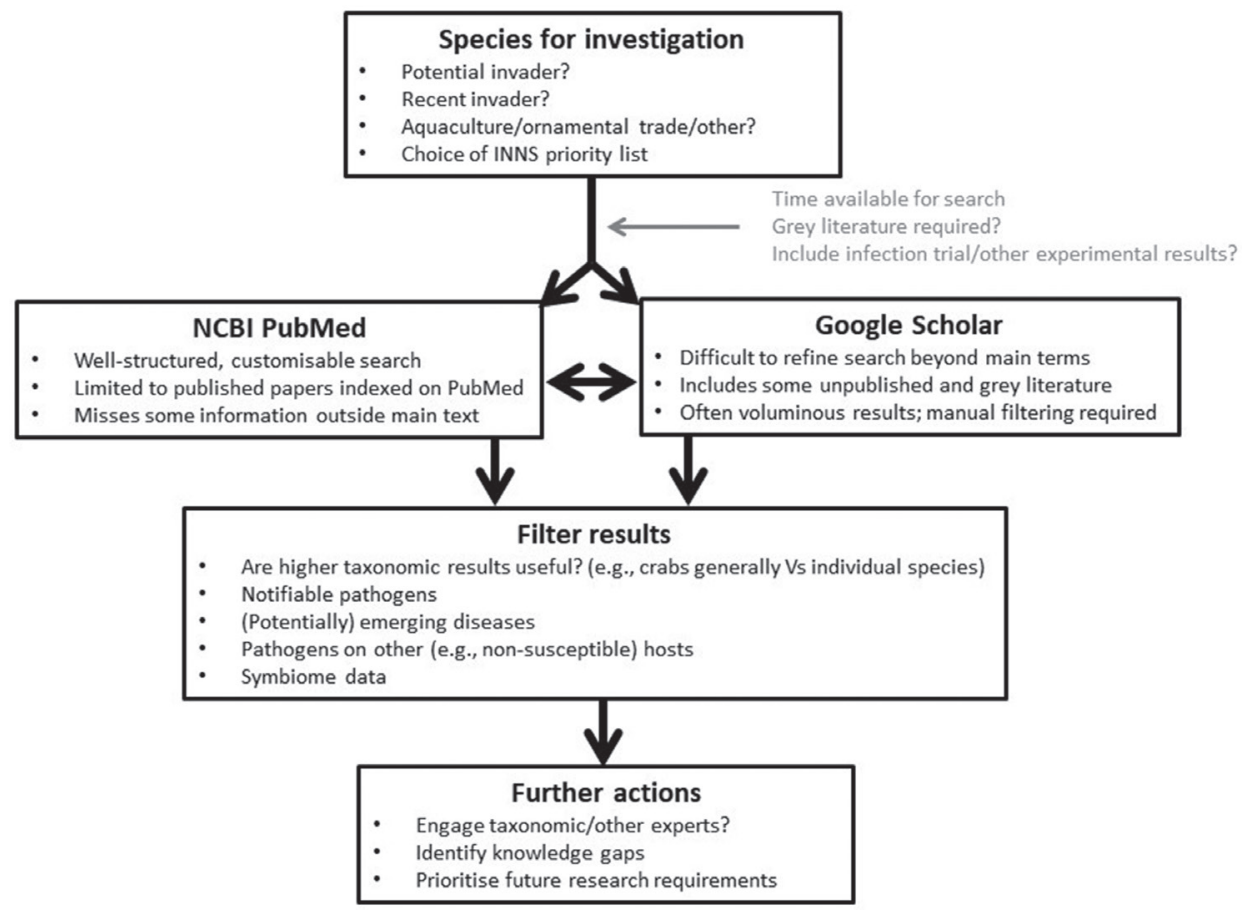

Figure 2. Workflow for investigating existing data relating to symbionts (including pathogens) of current and potential INNS. The bullet points in each box indicate key considerations for each step of this customisable process. The list of factors in gray text influence whether PubMed or Google Scholar (or both) would be more appropriate for the particular species being researched.

\section{Results}

Using PubMed; 34 of the 77 aquatic INNS were found to have no relevant literature relating to any known symbiotic species or pathogens. At genus level this number falls to 23; however, the relevance of symbionts and potential pathogens associated with the genus-level compared to the target species is uncertain but aids prediction. Symbiont and pathogen information extracted from the literature search for each species is listed in Suppl. material 1.

There were nine taxa for which species-level symbiont/pathogen data were published in 20+ papers; Neogobius melanostomus, Homarus americanus, Oncorhynchus gorbuscha, Carassius gibelio, Micropterus salmoides, Castor canadensis, Marsupenaeus japonicus, Myocaster coypus, and Ondatra zibethicus. The importance of these species in aquaculture, fisheries and human health is likely to explain their dominance within the literature. Homarus americanus, Marsupenaeus japonicus and Oncorhynchus gorbuscha are all highly valuable aquaculture species. Carassius gibelio and Micropterus salmoides are associated with the ornamental trade and recreational angling respectively. Castor canadensis, Myocaster coypus and Ondatra zibethicus carry multiple pathogens of human importance (see Suppl. material 1). 
The results from PubMed and Google Scholar show some similarity. For taxa with little relevant literature, Google Scholar was more likely to return relevant data. As shown in Table 1, only 26 of the 77 aquatic INNS returned no relevant literature through Google Scholar in comparison to 34 from PubMed. For taxa with more literature; PubMed returned a larger proportion of useful papers in fewer results, and although these were usually also identified in Google Scholar, significantly more manual sifting of results in order to find these papers was required. For example, Marsupenaeus japonicus had 65 relevant papers selected from PubMed, but only 28 were identified from the first 100 Google scholar results despite a vastly larger overall return. This is likely to be because PubMed allowed for a more targeted search. We found using both PubMed and Google Scholar in parallel gives the most comprehensive picture.

\section{Discussion}

PubMed search tools enabled a more accurate search as highly structured search criteria could be applied to just the title and abstract of papers, allowing a more focused search. However, the library of literature available in PubMed is smaller than on Google Scholar, and data from some figures and tables is not screened, sometimes leading to the omission of useful information. Google Scholar returned a significantly higher number of publications; the library of literature is much larger and it also scans grey literature and academic thesis repositories. However, Google Scholar also returns a much higher rate of irrelevant results which require significant manual sifting, in part because it scans the references of articles, and because the search cannot be narrowed by abstract. It is also important to scrutinize the source of literature from Google Scholar as it includes non-peer reviewed literature which may not always be suitable depending on the remit of the literature search. Haddaway et al. (2015) provides evidence to show that Google Scholar can be a powerful resource when used alongside other search methods; but is best used as a complementary tool.

Where there is a knowledge gap regarding the symbionts and pathogens of the target species, expert advice may be highly beneficial. This is likely to be the case for many known and potential INNS in most countries. Collaborative expert-elicitation is also a highly valuable tool within the field of biological invasion policy and has been implemented in numerous successful studies (Booy et al. 2017; Hughes et al. 2020; Peyton et al. 2019; Roy et al. 2014, 2017, 2018). These methods have been refined to ten guiding principles to consider within expert-elicitation to increase the effectiveness of this tool (see Roy et al. 2020).

When assessing the reliability of reports of co-transported pathogens in the literature, it is important to consider the methods used for their identification. Genetic signatures of pathogens may be associated with particular host samples in the literature, but these do not necessarily represent infections of those hosts; for example they could be passing through the gut and/or infecting host food items. Visualization techniques such as histopathology or in situ hybridization can be used to more precisely determine 
host-pathogen relationships initially inferred from molecular-only data. The use of such complementary techniques is recommended for research seeking to fill knowledge gaps such as those identified in this paper.

\section{Current INNS legislation}

Recognition of the negative impacts of INNS is evidenced by the increase in legislation and policy that aims to mitigate or reduce INNS impacts. Aichi Target 9 of the CBD commits signatories, of all member parties, to minimize new introductions of INNS, and control and eradicate priority species (UNEP 2011). This commitment is reflected in European legislation, including Regulation (EU) No 1143/2014 on the prevention and management of the introduction and spread of invasive species (EU 2014). There are additional legislative drivers within the EU to reduce the introduction and spread of INNS as a driver of environmental degradation (Water Framework Directive 2000/60/EC) and as an indication of human pressures (Marine Strategy Framework Directive 2008/56/EC).

\section{Current Pathogen legislation}

The World Organisation for Animal Health (OIE) has the mandate to prevent the spread of important animal pathogens, including those of aquatic animals (defined as amphibians, crustaceans, fish, and molluscs). OIE standards are recognized by the World Trade Organisation and applied within its Sanitary and Phytosanitary (SPS) agreement. The 182 members of the OIE include all major economies. National and supra-national (e.g., EU laws) need to be consistent with OIE standards. The EU Regulation 2016/429 (Animal Health Law) provides the legal basis to prevent the spread of important listed infectious pathogens. The criteria necessary for listing a pathogen include a significant negative impact on farmed animal production or biodiversity (through biosecurity, contingency planning, surveillance, and eradication) and will be applicable from 21 April 2021 (Council of Europe 2019).

Pathogens are recognized in the International Council for the Exploration of the Sea (ICES) Code of Practice on the "Introductions and Transfers of Marine Organisms", which has existed in some form since 1973 (ICES 2005). This sets out recommended procedures for the introduction of INNS for commercial reasons (e.g., aquaculture, bait) to ensure they are free of known pathogens (Turner 1988).

\section{Future INNS policy recommendations}

The CBD places a focus on the prevention of INNS introductions (followed by early detection and rapid response). Risk assessments of INNS are identified as a key element of the risk analysis process which is required for prioritising INNS for management. At an international level, countries under the SPS agreement must provide a risk assessment to support measures to prevent disease spread that go beyond international 
(OIE) standards. Co-transported pathogens, however, cannot be risk assessed, or regulated and controlled if they are unknown and unquantified. Therefore, we recommend 1) more intensive study of INNS and their associated symbionts (including known and potential pathogens), using both experimental and diagnostic evidence to support evidencing INNS risk assessments; 2) identification of high-risk potential INNS and recent invaders and targeted investigation; and 3) investigation of which INNS taxa might co-transport high risk pathogens, based on what we know of the pathogens/ symbionts of those groups more generally.

As suggested by Roy et al. (2017), the inclusion of information on pathogens within alien species databases, including the communication of such information, is critical to the success of management programs that aim to mitigate the impacts of pathogens co-transported with INNS. Future priorities should be to collect baseline information on the distribution and population dynamics of parasites, hosts and vectors, to determine the relative importance of invasion pathways, and to develop methods for predicting host shifts, parasites-host dynamics and the evolution of alien pathogens (Roy 2016). Many aspects of the study and management of emerging infectious diseases and biological invasions work in parallel. Collaboration across disciplines is important to effectively tackle these issues, such as adopting the One Health framework (Ogden et al. 2019; Bojko et al. 2020).

\section{Conclusion}

Invasion biology needs more robust methods for reliably evaluating the risks associated with INNS introductions (Kumschick et al. 2015). One of the most important factors to consider as part of risk assessments is evaluating the symbiome of INNS. Therefore, there is a need to better understand symbionts associated with INNS in order to evaluate the potential threat of emerging co-invasive pathogens as part of the INNS risk assessment processes (including horizon scanning). The workflow proposed in this paper uses a tested set of search terms in both PubMed and Google Scholar to thoroughly scan any available literature. This workflow aims to allow comprehensive data gathering of pathogens potentially co-transported with INNS, and constitutes a simple yet powerful methodology for the robust and standardized assessment of symbionts associated with INNS. As such, it provides a crucial step towards addressing the knowledge gaps regarding co-transportation of symbionts, facilitating integration of such knowledge into INNS risk assessment.

While limitations exist with respect to INNS data, the increasing use of histological, eDNA, and molecular diagnostics also offer new opportunities for monitoring INNS, potentially enabling the capture of pathological data more easily. Innovative modelling approaches, such as those using evolutionary trait-based frameworks (Barwell et al. 2020), can also inform horizon scanning and risk assessment to identify potentially impactful pathogens.

The introduction of INNS is widely recognized as important in both introducing known pathogens and a driver for the emergence of new pathogens (Peeler et al. 2011). There is a need at both international and national level for a collaborative ap- 
proach to the assessment of INNS, efficient resource use and the formulation of guidance and risk assessment tools to both prevent and control the introduction of INNS and their symbionts. INNS do not recognize political boundaries so their effective management, particularly within the marine environment, requires transboundary coordination and collaboration.

Improved awareness raising, in particular across key sectors and stakeholder groups, will be important for managing the threat of INNS and their symbionts. The proposed amendments to risk assessment processes should aid in the more appropriate identification of INNS risk, but this will also need to be incorporated into other aspects of risk analysis including horizon scanning, risk management and prioritization. Further, robust and standardized prevention and mitigation approaches are needed globally to implement suitable actions once a species has been prioritized. For example, pathway management, border checks (to include molecular based screening for symbionts) and quarantine for intentionally introduced INNS, and routine monitoring and rapid response following detection of unintentionally introduced INNS. The use of molecular based tool sets is increasingly becoming a go to option for the detection of INNS and will be a necessity for the detection symbionts they may carry. Explicit consideration of symbionts and potential for disease emergence should also be made within assessments undertaken prior to the translocation of both INNS and native species for conservation or assisted colonization purposes such as for aquaculture.

This issue is now more pressing than ever: climate change could act synergistically with other stressors, to increase the impacts of invading pathogens. Rising water temperatures may mean more INNS and their pathogens are able to survive and establish in the UK. Furthermore, the increasing global demands on aquaculture production, mean that impacts arising from emerging aquatic diseases are increasing in frequency, and have increasingly diverse and serious economic implications.

\section{Acknowledgements}

RF was supported by a PhD studentship co-funded by the NHM and Cefas. DB was supported by Defra projects FB002 and FC1215. HER is supported by the Natural Environment Research Council award number NE/R016429/1 as part of the UKSCAPE program delivering National Capability and through the Defra-funded GB Non-Native Species Information Portal. JB was supported by the Global Challenge Research Fund at Teesside University to develop outreach for understanding disease transmission via biological invasions.

\section{References}

Allain TW, Stentiford GD, Bass D, Behringer, DC, Bojko J (2020) A novel nudivirus infecting the invasive demon shrimp Dikerogammarus haemobaphes (Amphipoda). Scientific reports 10: 1-13. https://doi.org/10.1038/s41598-020-71776-3 
Amaral-Zettler LA, Schmidt V, Smith KF (2018) Microbial community and potential pathogen shifts along an ornamental fish supply chain. Microorganisms 6: e91. https://doi. org/10.3390/microorganisms6030091

Atalah J, Sanchez-Jerez P (2019) Global assessment of ecological risks associated with farmed fish escapes. Global Ecology and Conservation 21: e00842. https://doi.org/10.1016/j. gecco.2019.e00842.

Bailey SA, Brown L, Campbell ML, Canning-Clode J, Carlton JT, Castro N, Chainho P, Chan FT, Creed JC, Curd A, Darling J (2020) Trends in the detection of aquatic non-indigenous species across global marine, estuarine and freshwater ecosystems: A 50-year perspective. Diversity and Distributions 26: 1780-1797. https://doi.org/10.1111/ddi.13167

Barwell LJ, Perez-Sierra A, Henricot B, Harris A, Burgess TI, Hardy G, Scott P, Williams N, Cooke DEL, Green S, Chapman DS, Purse BV (2020) Evolutionary trait-based approaches for predicting future global impacts of plant pathogens in the genus Phytophthora. Journal of Applied Ecology 58(4): 1-13. https://doi.org/10.1111/13652664.13820

Bass D, Stentiford GD, Wang H, Koskella B, Tyler CR (2019) The pathobiome in animal and plant diseases. Trends in Ecology \& Evolution 3: 996-1008. https://doi.org/10.1016/j. tree.2019.07.012.

Bass D, Del Campo J (2020) Microeukaryotes in animal and plant microbiomes: Ecologies of disease? European Journal of Protistology 76: e125719. https://doi.org/10.1016/j. ejop.2020.125719

Blakeslee A, Manousaki T, Vasileiadou K, Tepolt CK (2020a) An evolutionary perspective on marine invasions. Evolutionary Applications 13: 479-485. https://doi.org/10.1111/ eva. 12906

Blakeslee AM, Haram L, Altman I, Kennedy K, Ruiz G, Miller AW (2020b). Founder effects and species introductions: A host versus parasite perspective. Evolutionary Applications 13: 559-574. https://doi.org/10.1111/eva.12868

Bojko J, Stebbing PD, Bateman KS, Meatyard JE, Bacela-Spychalska K, Dunn AM, Stentiford GD (2013) Baseline histopathological survey of a recently invading island population of 'killer shrimp', Dikerogammarus villosus. Diseases of Aquatic Organisms 106: 241-253. https://doi.org/10.3354/dao02658

Bojko J, Dunn AM, Stebbing PD, Ross SH, Kerr RC, Stentiford GD (2015) Cucumispora ornata n. sp. (Fungi: Microsporidia) infecting invasive 'demon shrimp' (Dikerogammarus haemobaphes) in the United Kingdom. Journal of Invertebrate Pathology 128: 22-30. https://doi.org/10.1016/j.jip.2015.04.005

Bojko J, Stebbing PD, Dunn AM, Bateman KS, Clark F, Kerr RC, Stewart-Clark S, Johannesen Á, Stentiford GD (2018) Green crab Carcinus maenas symbiont profiles along a North Atlantic invasion route. Diseases of Aquatic Organisms 128: 147-168. https://doi. org/10.3354/dao03216

Bojko J, Stentiford GD, Stebbing PD, Hassall C, Deacon A, Cargill B, Dunn AM (2019) Pathogens of Dikerogammarus haemobaphes regulate host activity and survival, but also threaten native amphipod populations in the UK. Diseases of Aquatic Organisms 136: 63-78. https://doi.org/10.3354/dao03195 
Bojko J, Ovcharenko M (2019) Pathogens and other symbionts of the Amphipoda: taxonomic diversity and pathological significance. Diseases of Aquatic Organisms 136: 3-36. https:// doi.org/10.3354/dao03321

Bojko J, Burgess AL, Baker AG, Orr CH (2020) Invasive non-native crustacean symbionts: Diversity and impact. Journal of Invertebrate Pathology 2020: e107482. https://doi. org/10.1016/j.jip.2020.107482

Booy O, Mill AC, Roy HE, Hiley A, Moore N, Robertson P, Baker S, Brazier M, Bue M, Bullock R, Campbell S, Eyre D, Foster J, Hatton-Ellis M, Long J, Macadam C, Morrison-Bell C, Mumford J, Newman J, Parrott D, Payne R, Renals T, Rodgers E, Spencer M, Stebbing P, Sutton-Croft M, Walker K J, Ward A, Whittaker S, Wyn G (2017) Risk management to prioritise the eradication of new and emerging invasive non-native species. Biological Invasions 19: 2401-2417. https://doi.org/10.1007/s10530-017-1451-z

Chalkowski K, Lepczyk CA, Zohdy S (2018) Parasite ecology of invasive species: conceptual framework and new hypotheses. Trends in Parasitology 34: 655-663. https://doi. org/10.1016/j.pt.2018.05.008.

Chinchio E, Crotta M, Romeo C, Drewe JA, Guitian J, Ferrari N (2020) Invasive alien species and disease risk: An open challenge in public and animal health. PLoS Pathology 16: e1008922. https://doi.org/10.1371/journal.ppat.1008922

Convention on Biological Diversity (2010). What Are Invasive Alien Species? https://www.cbd. int/invasive/WhatareIAS.shtml

Colautti RI, Ricciardi A, Grigorovich IA, MacIsaac HJ (2004) Is invasion success explained by the enemy release hypothesis? Ecology Letters 7: 721-733. https://doi.org/10.1111/ j.1461-0248.2004.00616.x

Cottier-Cook EJ, Beveridge C, Bishop JDD, Brodie J, Clark PF, Epstein G, Jenkins SR, Johns DG, Loxton J, MacLeod A, Maggs C, Minchin D, Mineur F, Sewell J, Wood CA (2017) Non-native species. Marine Climate Change Impacts Partnership Science Review 47-61. https://dx.doi.org/10.14465/2017.arc10.005-nns

Council of Europe (2019) Report on Alien Pathogens and Pathogens Spread by Invasive Alien Species in Europe. https://rm.coe.int/report-on-alien-pathogens-and-pathogens-spreadby-ias-draft-1/168096e1e9

Dermott R, Witt J, Urn-Young M, Gonzales M (1998) Distribution of Ponto-Caspian amphipod Echinogammarus ischnus in the Great Lakes and replacement of native Gammarus fasciatus. Journal of Great Lakes Research 24: 442-452. https://doi.org/10.1016/S03801330(98)70834-2

Dick JT, Laverty C, Lennon JJ, Barrios-O’Neill D, Mensink PJ, Britton JR, Médoc V, Boets P, Alexander ME, Taylor NG, Dunn AM, Hatcher MJ, Rosewarne PJ, Crookes SH, MacIsaac J, Xu M, Ricciardi A, Wasserman RJ, Ellender BR, Weyl OLF, Lucy FE, Banks PB, Dodd JA, MacNeil C, Penk MR, Aldridge DC, Caffrey JM (2017) Invader Relative Impact Potential: a new metric to understand and predict the ecological impacts of existing, emerging and future invasive alien species. Journal of Applied Ecology 54: 1259-1267. https://doi. org/10.1111/1365-2664.12849

Duggan IC (2010) The freshwater aquarium trade as a vector for incidental invertebrate fauna. Biological Invasions 12: 3757-3770. https://doi.org/10.1007/s10530-010-9768-x 
Dunn AM, Hatcher MJ(2015) Parasites and biological invasions: parallels, interactions, and control. Special Issue: Wildlife Parasitology. Trends in Parasitology 31: e5. https://doi. org/10.1016/j.pt.2014.12.003

Dutta H, Dutta A (2016) The microbial aspect of climate change. Energy Ecology \& Environment 1: 209-232. https://doi.org/10.1007/s40974-016-0034-7

EU (2014) Council Regulation No 1143/2014 of the Council of 22 October 2014 concerning the prevention and management of the introduction and spread of invasive alien species. Official Journal of the European Union, 57: e35. https://eur-lex.europa.eu/legal-content/ EN/TXT/?uri=CELEX\%3A32014R1143

Fisher MC, Garner TWJ (2007) The relationship between the emergence of Batrachochytrium dendrobatidis, the wildlife trade in amphibians and introduced amphibian species. Fungal Biology Review 21: 2-9. https://doi.org/10.1016/j.fbr.2007.02.002

GBNNSS (2019) Non native species information portal project: horizon scanning exercise. https://secure.fera.defra.gov.uk/nonnativespecies/ downloadDocument.cfm?id=2481

Haddaway NR, Collins AM, Coughlin D, Kirk S (2015) The role of Google Scholar in evidence reviews and its applicability to grey literature searching. PloS ONE 10: e0138237. https://doi.org/10.1371/journal.pone.0138237

Hess-Erga OK, Moreno-Andrés J, Enger Ø, Vadstein O (2019) Microorganisms in ballast water: Disinfection, community dynamics, and implications for management. The Science of the total environment 657: 704-716. https://doi.org/10.1016/j.scitotenv.2018.12.004

Hughes KA, Pescott OL, Peyton J, Adriaens T, Cottier-Cook EJ, Key G, Rabitsch W, Tricarico E, Barnes DKA, Baxter N, Belchier M, Blake D, Convey P, Dawson W, Frohlich D, Gardiner LM, González-Moreno P, James R, Malumphy C, Martin S, Martinou AF, Minchin D, Monaco A, Moore N, Morley SA, Ross K, Shanklin J, Turvey K, Vaughan D, Vaux AGC, Werenkraut V, Winfield IJ, Roy HE (2020) Invasive non-native species likely to threaten biodiversity and ecosystems in the Antarctic Peninsula region. Global Change Biology 26: 2702-2716. https://doi.org/10.1111/gcb.14938

Hulme PE (2014) Invasive species challenge the global response to emerging diseases. Trends in Parasitology 30: 267-270. https://doi.org/10.1016/j.pt.2014.03.005

Hulme PE, Bacher S, Kenis M, Klotz S, Kühn I, Minchin D, Nentwig W, Olenin S, Panov V, Pergl J, Pyšek P, Roques A, Sol D, Solarz W, Vilà M (2008) Grasping at the routes of biological invasions: a framework for integrating pathways into policy. Journal of Applied Ecology 45: 403-414. https://doi.org/10.1111/j.1365-2664.2007.01442.x

ICES (2005) ICES Code of Practice on the Introductions and Transfers of Marine Organisms 2005. https://www.nobanis.org/globalassets/ices-code-of-practice.pdf

IPBES (2019) Summary for policymakers of the global assessment report on biodiversity and ecosystem services of the Intergovernmental Science-Policy Platform on Biodiversity and Ecosystem Services. In: Díaz S, Settele J, Brondízio ES, Ngo HT, Guèze M, Agard J, Arneth A, Balvanera P, Brauman KA, Butchart SHM, Chan KMA, Garibaldi LA, Ichii K, Liu J, Subramanian SM, Midgley GF, Miloslavich P, Molnár Z, Obura D, Pfaff A, Polasky S, Purvis A, Razzaque J, Reyers B, Chowdhury RR, Shin YJ, Visseren-Hamakers IJ, Willis KJ, Zayas CN (Eds) IPBES secretariat, Bonn. https://doi.org/10.5281/zenodo.3553579

Jennings S, Stentiford GD, Leocadio AM, Jeffery KR, Metcalfe JD, Katsiadaki I, Auchterlonie NA, Mangi SC, Pinnegar JK, Ellis T, Peeler EJ, Luisetti T, Baker-Austin C, Brown M, 
Catchpole TL, Clyne FJ, Dye SR, Edmonds NJ, Hyder K, Lee J, Lees DN, Morgan OC, O’Brien CM, Oidtmann B, Posen PE, Santos AR, Taylor NGH, Turner AD, Townhill BL, Verner-Jeffreys DW(2016) Aquatic food security: insights into challenges and solutions from an analysis of interactions between fisheries, aquaculture, food safety, human health, fish and human welfare, economy and environment. Fish and Fisheries 17: 893-938. https://doi.org/10.1111/faf.12152

Keane RM, Crawley MJ (2002) Exotic plant invasions and the enemy release hypothesis. Trends in Ecology \& Evolution 17: 164-170. https://doi.org/10.1016/S0169-5347(02)02499-0

Kelly DW, Paterson RA, Townsend CR, Poulin R, Tompkins DM (2009) Parasite spillback: A neglected concept in invasion ecology? Ecology 90: 2047-2056. https://doi. org/10.1890/08-1085.1

Kestrup ÅM, Thomas SH, van Rensburg K, Ricciardi A, Duffy MA (2011) Differential infection of exotic and native freshwater amphipods by a parasitic water mold in the St. Lawrence River. Biological Invasions 13: 769-779. https://doi.org/10.1007/s10530-0109867-8

Kumschick S, Bacher S, Evans T, Marková Z, Pergl J, Pyšek P, Vaes-Petignat S, Veer G, Vilà M, Nentwig W (2015) Comparing impacts of alien plants and animals in Europe using a standard scoring system. Journal of Applied Ecology 52: 552-561. https://doi. org/10.1111/1365-2664.12427

Lymbery AJ, Morine M, Kanani HG, Beatty SJ, Morgan DL (2014) Co-invaders: The effects of alien parasites on native hosts. International Journal of Parasitology, Parasites \& Wildlife. 3: 171-177. https://doi.org/10.1016/j.ijppaw.2014.04.002

Mahon AR, Horton DJ, Learman DR, Nathan LR, Jerde CL (2018) Investigating diversity of pathogenic microbes in commercial bait trade water. PeerJ 6: e5468. https://doi. org/10.7717/peerj.5468

Meres NJ, Ajuzie CC, Sikaroodi M, Vemulapalli M, Shields JD, Gillevet PM (2012) Dysbiosis in epizootic shell disease of the American lobster (Homarus americanus). Journal of Shellfish Research 31: 463-472. https://doi.org/10.2983/035.031.0206

Morens DM, Folkers GK, Fauci AS (2004) The challenge of emerging and re-emerging infectious diseases. Nature 430: 242-249. https://doi.org/10.1038/nature02759

Mrugała A, Kozubíková-Balcarová E, Chucholl C, Cabanillas S, Viljamaa-Dirks S, Vukić J, Petrusek A (2015) Trade of ornamental crayfish in Europe as a possible introduction pathway for important crustacean diseases: crayfish plague and white spot syndrome. Biological Invasions 17: 1313-1326. https://doi.org/10.1007/s10530-014-0795-x.

Ng TH, Tan SK, Wong WH, Meier R, Chan SY, Tan HH, Yeo DCJ (2016) Molluscs for sale: Assessment of freshwater gastropods and bivalves in the ornamental pet trade. PLoS ONE 11: e0161130. https://doi.org/10.1371/journal.pone.0161130

Nunes A, Tricarico E, Panov V, Cardoso A, Katsanevakis S (2015) Pathways and gateways of freshwater invasions in Europe. Aquatic Invasions 10: 359-370. https://doi.org/10.3391/ ai.2015.10.4.01

Ogden N, Wilson J, Richardson D, Hui C, Davies S, Kumschick S, Le Roux J, Measey J, Saul W, Pulliam J (2019) Emerging infectious diseases and biological invasions: A call for a One Health collaboration in science and management. Royal Society Open Science 6. https:// doi.org/10.1098/rsos. 181577. 
Ojaveer H, Galil BS, Campbell ML, Carlton JT, Canning-Clode J, Cook EJ, Davidson AD, Hewitt CL, Jelmert A, Marchini A, McKenzie CH (2015) Classification of non-indigenous species based on their impacts: considerations for application in marine management. PLoS Biology 13: e1002130. https://doi.org/10.1371/journal.pbio.1002130

Ormerod SJ, Durance I, Hatton-Ellis TW, Cable J, Chadwick EA, Griffiths S, Jones TH, Larsen S, Merrix FL, Symondson WOC, Thomas RJ, Vaughan IP (2011) Landscape Connectivity of Freshwater Ecosystems: Strategic Review and Recommendations. CCW Contract Science Report No: 932, CCW, Bangor.

Ovcharenko M, Codreanu-Balcescu D, Grabowski M, Konopacka A, Wita I, Czaplinska U (2009) Gregarines (Apicomplexa) and microsporidians (Microsporidia) of native and invasive gammarids (Amphipoda, Gammaroidea), occurring in Poland. Wiadomości Parazytologiczne 55: 237-247. https://doi.org/10.2478/v10232-011-0017-9

Ovcharenko M, Bacela K, Wilkinson T, Ironside J, Rigaud T, Wattier RA (2010) Cucumispora dikerogammari n. gen. (Fungi: Microsporidia) infecting the invasive amphipod Dikerogammarus villosus: a potential emerging disease in European rivers. Parasitology 137: 191-204. https://doi.org/10.1017/S0031182009991119

Padilla DK, Williams SL (2004) Beyond ballast water: aquarium and ornamental trades as sources of invasive species in aquatic ecosystems. Frontiers in Ecology and the Environment, 2: 131-138. https://doi.org/10.1890/15409295(2004)002[0131:BBWAAO]2.0.CO;2

Pagenkopp Lohan KM, Ruiz G, Torchin M (2020). Invasions can drive marine disease dynamics. In: Behringer DC, Silliman BR, Lafferty KD (Eds) Drivers of Marine Disease, Marine Disease Ecology. Oxford Scholarship Online. https://doi.org/10.1093/ oso/9780198821632.003.0007

Patoka J, Magalhães ALB, Kouba A, Faulkes Z, Jerikho R, Ricardo J, Vitule S (2018) Invasive aquatic pets: failed policies increase risks of harmful invasions. Biodiversity \& Conservation 27: 3037-3046. https://doi.org/10.1007/s10531-018-1581-3

Peeler EJ, Oidtmann BC, Midtlyng PJ, Miossec L, Gozlan RE (2011) Non-native aquatic animals introductions have driven disease emergence in Europe. Biological Invasions 13: 1291-1303. https://doi.org/10.1007/s10530-010-9890-9

Pergl J, Brundu G, Harrower CA, Cardoso AC, Genovesi P, Katsanevakis S, Lozano V, Perglová I, Rabitsch W, Richards G, Roques A, Rorke SL, Scalera R, Schönrogge K, Stewart A, Tricarico E, Tsiamis K, Vannini A, Vilà M, Zenetos A, Roy HE (2020) Applying the Convention on Biological Diversity Pathway Classification to alien species in Europe. In: Wilson JR, Bacher S, Daehler CC, Groom QJ, Kumschick S, Lockwood JL, Robinson TB, Zengeya TA, Richardson DM. NeoBiota 62: 333-363. https://doi.org/10.3897/neobiota.62.53796 Peyton J, Martinou AF, Pescott OL, Demetriou M, Adriaens T, Arianoutsou M, Bazos I, Bean CW, Booy O, Botham M, Britton JR, Cervia JL, Charilaou P, Chartosia N, Dean HJ, Delipetrou P, Dimitriou AC, Dörflinger G, Fawcett J, Fyttis G, Galanidis A, Galil BS, Hadjikyriakou T, Hadjistylli M, Ieronymidou C, Jimenez C, Karachle P, Kassinis N, Kerametsidis G, Kirschel ANG, Kleitou P, Kleitou D, Manolaki P, Michailidis N, Mountford JO, Nikolaou C, Papatheodoulou A, Payiatas G, Ribeiro F, Rorke SL, Samuel Y, Savvides P, Schafer SM, Tarkan AS, Silva-Rocha I, Top N, Tricarico E, Turvey K, Tziortzis I, Tzirkalli E, Verreycken H, Winfield IJ, Zenetos A, Roy HE (2019) Horizon scanning for invasive alien 
species with the potential to threaten biodiversity and human health on a Mediterranean island. Biological Invasions 21: 2107-2125. https://doi.org/10.1007/s10530-019-01961-7 Pochon X, Bott NJ, Smith KF, Wood SA (2013) Evaluating detection limits of next-generation sequencing for the surveillance and monitoring of international marine pests. PLoS ONE 8: e73935. https://doi.org/10.1371/journal.pone.0073935

Prenter J, MacNeil C, Dick JTA, Dunn AM (2004) Roles of parasites in animal invasions. Trends in Ecology and Evolution 19: 385-390. https://doi.org/10.1016/j.tree.2004.05.002 Power AG, Mitchell CE (2004) Pathogen spillover in disease epidemics. American Naturalist 164. https://doi.org/10.1086/424610

Rahel FJ, Olden JD (2008) Assessing the effects of climate change on aquatic invasive species. Conservation Biology 22: 521-533. https://doi.org/10.1111/j.1523-1739.2008.00950.x

Robinson C, Webster T, Cable J, James J, Consuegra S (2018) Simultaneous detection of invasive signal crayfish, endangered white-clawed crayfish and the crayfish plague pathogen using environmental DNA. Biological Conservation 222: 241-252. https://doi. org/10.1016/j.biocon.2018.04.009

Roy HE, Peyton J, Aldridge DC, Bantock T, Blackburn TM, Britton R, Clark PF, Cook E, Dehnen-Schmutz K, Dines T, Dobson M, Edwards F, Harrower C, Harvey MC, Minchin D, Noble DG, Parrott D, Pocock MJO, Preston CD, Roy S, Salisbury A, Schönrogge K, Sewell J, Shaw RH, Stebbing P, Stewart AJA, Walker KJ (2014) Horizon scanning for invasive alien species with the potential to threaten biodiversity in Great Britain. Global Change Biology 20: 3859-3871. https://doi.org/10.1111/gcb.12603

Roy HE (2016) Control wildlife pathogens too. Nature 530: e281. https:/doi. org/10.1038/530281d

Roy HE, Hesketh H, Purse BV, Eilenberg J, Santini A, Scalera R, Stentiford GD, Adriaens T, Bacela-Spychalska K, Bass D, Beckmann KM, Bessell P, Bojko J, Booy O, Cardoso AC, Essl F, Groom Q, Harrower C, Kleespies R, Martinou AF, Oers MM, Peeler EJ, Pergl J, Rabitsch W, Roques A, Schaffner F, Schindler S, Schmidt BR, Schönrogge K, Smith J, Solarz W, Stewart A, Stroo A, Tricarico E, Turvey KM, Vannini A, Vilà M, Woodward S, Wynns AA, Dunn AM (2017) Alien pathogens on the horizon: Opportunities for predicting their threat to wildlife. Conservation Letters 10: 477-484. https://doi.org/10.1111/ conl.12297

Roy HE, Rabitsch W, Scalera R, Stewart A, Gallardo B, Genovesi P, Essl F, Adriaens T, Bacher S, Booy O, Branquart E, Brunel S, Copp GH, Dean H, D’hondt B, Josefsson M, Kenis M, Kettunen M, Linnamagi M, Lucy F, Martinou A, Moore N, Nentwig W, Nieto A, Pergl J, Peyton J, Roques A, Schindler S, Schönrogge K, Solarz W, Stebbing P, Trichkova T, Vanderhoeven S, van Valkenburg J, Zenetos A (2018) Developing a framework of minimum standards for the risk assessment of alien species. Journal of Applied Ecology 55: 526-538. https://doi.org/10.1111/1365-2664.13025

Roy HE, Peyton JM, Booy O (2020) Guiding principles for utilizing social influence within expert-elicitation to inform conservation decision-making. Global Change Biology 26: 3181-3184. https://doi.org/10.1111/gcb.15062

Rueckert S, Betts EL, Tsaousis AD (2019) The symbiotic spectrum: Where do the gregarines fit? Trends in Parasitology 35: 687-694. https://doi.org/10.1016/j.pt.2019.06.013 
Sheath DJ, Williams CF, Reading AJ, Britton JR (2015) Parasites of non-native freshwater fishes introduced into England and Wales suggest enemy release and parasite acquisition. Biological Invasions 17: 2235-2246. https://doi.org/10.1007/s10530-015-0857-8

Skillings D (2016) Holobionts and the ecology of organisms: Multi-species communities or integrated individuals? Biology \& Philosophy 31: 875-892. https://doi.org/10.1007/ s10539-016-9544-0

Smith KF, Yabsley MJ, Sanchez S, Casey CL, Behrens MD, Hernandez SM (2012) Salmonella isolates from wild-caught Tokay geckos (Gekko gecko) imported to the U.S. from Indonesia. Vector-Borne \& Zoonotic Diseases 12: 575-582. https://doi.org/10.1089/vbz.2011.0899

Stentiford GD, Flegel TW, Williams BAP, Withyachumnarnkul B, Itsathitphaisarn O, Sritunyalucksana K, Bass D (2017) New paradigms to solve the global aquaculture disease crisis. PLoS Pathogens 13: e1006160. https://doi.org/10.1371/journal.ppat.1006160

Stentiford GD, Bateman IJ, Hinchliffe SJ, Bass D, Hartnell R, Santos EM, Devlin MJ, Feist SW, Taylor NGH, Verner-Jeffreys DW, van Aerle R, Peeler EJ, Higman WA, Smith L, Baines R, Behringer DC, Katsiadaki I, Froehlich HE, Tyler CR (2020) Sustainable aquaculture through the One Health lens. Nature Food 1: 468-474. https://doi.org/10.1038/ s43016-020-0127-5

Stranga Y, Katsanevakis S (2021) Eight years of BioInvasions Records: patterns and trends in alien and cryptogenic species records. Management of Biological Invasions 12: 221-239, https://doi.org/10.3391/mbi.2021.12.2.01

Seebens H, Bacher S, Blackburn TM, Capinha C, Dawson W, Dullinger S, Genovesi P, Hulme PE, van Kleunen M, Kühn I, Jeschke JM, Lenzner B, Liebhold AM, Pattison Z, Pergl J, Pyšek P, Winter M, Essl F (2020) Projecting the continental accumulation of alien species through to 2050. Global Change Biology 27: 970-982. https://doi.org/10.1111/gcb.15333

Subramaniam K, Behringer DC, Bojko J, Yutin N, Clark AS, Bateman KS, van Aerle R, Bass D, Kerr R, Koonin EV, Waltzek TB (2020) A new family of DNA viruses causing disease in crustaceans from diverse aquatic biomes. MBio 11: e02938-19. https://doi.org/10.1128/ mBio.02938-19

Taraschewski H (2006) Hosts and parasites as aliens. Journal of Helminthology 80: 99-128. https://doi.org/10.1079/JOH2006364

Tepolt CK, Darling JA, Blakeslee A, Fowler AE, Torchin ME, Miller AW, Ruiz GM (2019) Recent introductions reveal differential susceptibility to parasitism across an evolutionary mosaic. Evolutionary applications 13: 545-558. https://doi.org/10.1111/eva.12865

Thaku MP, van der Putten WH, Cobben MMP, van Kleunen M, Geisen S (2019) Microbial invasions in terrestrial ecosystems. Nature Reviews Microbiology 17: 621-631. https://doi. org/10.1038/s41579-019-0236-z

Thieltges D, Reise K, Prinz K, Jensen K (2008) Invaders interfere with native parasite-host interactions. Biological Invasions 11: 1421-1429. https://doi.org/10.1007/s10530-008-9350-y

Thomaz SM, Kovalenko KE, Havel JE, Kats LB (2015) Aquatic invasive species: general trends in the literature and introduction to the special issue. Hydrobiologia 746: 1-12. https:// doi.org/10.1007/s10750-014-2150-8 
Tidbury HJ, Taylor NG, Copp GH, Garnacho E, Stebbing PD (2016) Predicting and mapping the risk of introduction of marine non-indigenous species into Great Britain and Ireland. Biological Invasions 18: 3277-3292. https://doi.org/10.1007/s10530-016-1219-x

Tilmans M, Mrugała A, Svoboda J, Engelsma MY, Petie M, Soes DM, Nutbeam-Tuffs S, Oidtmann B, Roessink I, Petrusek A (2014) Survey of the crayfish plague pathogen presence in the Netherlands reveals a new Aphanomyces astaci carrier. Journal of Invertebrate Pathology 120: 74-79. https://doi.org/10.1016/j.jip.2014.06.002

Turner GE (1988) Codes of practice and manual of procedures for consideration of introductions and transfers of marine and freshwater organisms. EIFAC/CECPI http://www.fao. org/3/ae989e/AE989E00.htm\#TOC

UNEP (2011) The strategic plan for biodiversity 2011-2020 and the Aichi biodiversity targets. https://www.cbd.int/sp/targets/

Vilcinskas A (2015) Pathogens as biological weapons of invasive species. PLoS Pathog, 11: e1004714. https://doi.org/10.1371/journal.ppat.1004714

Wood C, Bishop J, Davies C, Delduca E, Hatton J, Herbert R, Clark PF (2005) Hemigrapsus takanoi Asakura and Watanabe, 2005 (Crustacea: Decapoda: Brachyura: Grapsoidea): first records of the brush-clawed shore crab from Great Britain. BioInvasions Records 4: 109-113. https://doi.org/10.3391/bir.2015.4.2.07

\section{Appendix}

Table A I. Glossary.

\begin{tabular}{l|l}
\hline Symbiont & $\begin{array}{l}\text { Host-associated organisms and viruses, including long-term or transitory associations, epibionts } \\
\text { and endobionts. }\end{array}$ \\
\hline Pathogen & $\begin{array}{l}\text { A symbiont that causes disease in certain hosts under certain conditions. Its presence need not } \\
\text { result in disease. Often used interchangeably with 'parasite'. }\end{array}$ \\
\hline Parasite & $\begin{array}{l}\text { A symbiont that derives nutrition/material resource from its host in one of several ways, not } \\
\text { necessarily resulting in disease. Includes indirect feeding types including host stomach contents or } \\
\text { metabolic products. Often used interchangeably with 'pathogen'. }\end{array}$ \\
\hline $\begin{array}{l}\text { Enemy Release } \\
\text { Hypothesis }\end{array}$ & $\begin{array}{l}\text { INNS can lose their parasites as they move into a new range, thus increasing host biological fitness } \\
\text { as the resources used to fight the infection are no longer required (Keane and Crawley 2002). }\end{array}$ \\
\hline $\begin{array}{l}\text { Parasite } \\
\text { Spillback }\end{array}$ & $\begin{array}{l}\text { INNS can acquire parasites from the new range, resulting in parasite spillback to native species } \\
\text { by increasing the population of infected individuals (Sheath et al. 2015), thus changing disease } \\
\text { dynamics of infected native species at individual and population scale levels (Kelly et al. 2009). }\end{array}$ \\
\hline $\begin{array}{l}\text { Parasite } \\
\text { Spillover }\end{array}$ & $\begin{array}{l}\text { When parasites from INNS are transmitted to susceptible native host species (Power and Mitchell } \\
\text { 2004). }\end{array}$ \\
\hline $\begin{array}{l}\text { Disease } \\
\text { Facilitation } \\
\text { Hypothesis }\end{array}$ & $\begin{array}{l}\text { INNS may act as 'disease facilitators' by aiding the physical transfer of parasites through acting } \\
\text { as vectors or a reservoir, or via their role in habitat alteration which may improve parasite } \\
\text { environmental conditions (Chalkowski et al. 2018). }\end{array}$ \\
\hline Co-transport & $\begin{array}{l}\text { Organisms which are transported with an alien host to a new location outside of their native range } \\
\text { (Lymbery et al. 2014) }\end{array}$ \\
\hline $\begin{array}{l}\text { Heteroecious } \\
\text { parasites }\end{array}$ & \begin{tabular}{l} 
A parasite that requires at least two hosts. \\
\hline
\end{tabular} \\
\hline
\end{tabular}




\section{Supplementary material I}

\section{Table S1}

Authors: Rachel Foster

Data type: literature workflow results

Explanation note: This table shows known pathogens, potential pathogens, and symbionts of each INNS found using the proposed literature search workflow, with specific references (superscript numbers) listed below the table.

Copyright notice: This dataset is made available under the Open Database License (http://opendatacommons.org/licenses/odbl/1.0/). The Open Database License $(\mathrm{ODbL})$ is a license agreement intended to allow users to freely share, modify, and use this Dataset while maintaining this same freedom for others, provided that the original source and author(s) are credited.

Link: https://doi.org/10.3897/neobiota.69.71358.suppl1

\section{Supplementary material 2}

\section{Table S2}

Authors: Rachel Foster

Data type: rerefence list

Explanation note: This table lists all the references found using the proposed workflow as shown in Table 1 in the manuscript for PubMed.

Copyright notice: This dataset is made available under the Open Database License (http://opendatacommons.org/licenses/odbl/1.0/). The Open Database License $(\mathrm{ODbL})$ is a license agreement intended to allow users to freely share, modify, and use this Dataset while maintaining this same freedom for others, provided that the original source and author(s) are credited.

Link: https://doi.org/10.3897/neobiota.69.71358.suppl2

\section{Supplementary material 3}

\section{Table S3}

Authors: Rachel Foster

Data type: Reference list

Explanation note: This table lists all the references found using the proposed workflow as shown in Table 1 in the manuscript for Google Scholar.

Copyright notice: This dataset is made available under the Open Database License (http://opendatacommons.org/licenses/odbl/1.0/). The Open Database License $(\mathrm{ODbL})$ is a license agreement intended to allow users to freely share, modify, and use this Dataset while maintaining this same freedom for others, provided that the original source and author(s) are credited.

Link: https://doi.org/10.3897/neobiota.69.71358.suppl3 